\title{
Occurrence of Pseudodiaptomus gracilis (F. Dahl, 1894), Copepoda, Calanoida in amazonian fresh waters
}

\author{
Matsumura-Tundisi, T.* and Tundisi, J.G. \\ Instituto Internacional de Ecologia, São Carlos, Laboratório de Limnologia, \\ Rua Bento Carlos, 750, CEP 13560-660 São Carlos, SP, Brazil \\ *e-mail: tmt.iie@iie.com.br \\ Received June 20, 2006 - Accepted August 21, 2006 - Distributed August 31, 2007
}

(With 2 figures)

Among the family Pseudodiaptomidae, the genus Pseudodiaptomus assemblage of the blackish species shows a worldwide distribution (Walter, 1986). Most of them occur in estuaries in the neotropical region. In the Brazilian coastline, two species (Pseudodiaptomus acutus and Pseudodiaptomus richardi) are widely distributed from north to south constituting important material for various studies (Tundisi and MatsumuraTundisi, 1968; Cipolli and Carvalho, 1973; Prado-Por and Lansac-Toha, 1984; Magalhães et al, 2006.).

Nevertheless, the species Pseudodiaptomus gracilis has been registered in fresh water by several authors. According to Wright, 1936 the species is widely distributed in the lower Amazon region. It was recorded by Dahl, 1894 in freshwater at the mouth of the Rio Tocantins (Baia do Marajó). Wright, 1928, based on the Merril collection, reported the occurrence of Pseudodiaptomus gracilis in fresh water in the Lago Arary and Rio Arama, Marajó and in a bayou west of Santarem near where the Tapajoz joins the Amazon. Wright (also in 1935) collected at various points between the mainland at Belém and Marajo Island (Rio do Pará). Dussart, 1984 found the species in Venezuela in a pond near the Orinoco River at Barrancas. $P$. gracilis has been found also in brackish water (Stingelin, 1904) on the Marajó Island.

The occurrence of Pseudodiaptomus gracilis (Dahl, 1894) was observed in the material obtained from Rio
Xingu (Pará) during the limnological studies carried out at several points of the river located between the coordinates: $02^{\circ} 04^{\prime} 02^{\prime \prime} \mathrm{S}-03^{\circ} 55^{\prime} 16^{\prime \prime} \mathrm{S}$ and $51^{\circ} 30^{\prime} 13^{\prime \prime} \mathrm{W}$ - 53 $33^{\circ} 49^{\prime \prime} \mathrm{W}$ on an expedition on January, 2007

In the two places (RX15- Xingu River and BAC 01River Bacaje) a great population of Pseudodiaptomus gracilis was found. The limnological characteristics of these places are presented in Table 1 .

\section{Comments}

Pseudodiaptomus gracilis seems be an endemic species with its occurrence restricted to the Amazon region more in the freshwater than in brackish water. The conductivity of the samples where the species occurred showed the values $21.0 \mu \mathrm{S} . \mathrm{cm}^{-1}$ and $9.0 \mu \mathrm{S} . \mathrm{cm}^{-1}$, the $\mathrm{pH}$ 7.5 and dissolved oxygen between 7.5 to $8.0 \mathrm{mg} . \mathrm{L}^{-1}$

The species shows an opposite behavior of two other species ( $P$. acutus and $P$. richardi) that are from brackish water and are able to tolerate high salinity. This could be a case of a "reciprocal biological gradient" as reported by Tundisi (1970) for the lagunar region of Cananeia (SP).

Figure 1 shows the general aspects of the female (a) and male (b) and Figure 2 the aspect of the fifth leg of the male. The peculiar characteristic of this species is the length of the abdomen as near as the size of cephalothorax.

Table 1. Sampling sites in the river Xingu (Pará), where Pseudodiaptomus gracilis was found and its chemical characterization.

\begin{tabular}{|c|c|c|}
\hline \multirow[b]{3}{*}{ Coordinates: } & \multicolumn{2}{|c|}{ Places } \\
\hline & RX-15 (Xingu river) & BAC-01 (Bacajé river) \\
\hline & $2^{\circ} 49^{\prime} 13.5$ ' $\mathrm{S}$ and $46^{\circ} 00^{\prime} 42.7^{\prime \prime} \mathrm{W}$ & $3^{\circ} 30^{\prime} 5 ., 7^{\prime} ' \mathrm{~S}$ and $45^{\circ} 42^{\prime} 39.4 \prime \mathrm{W}$ \\
\hline Local depth (m) & 4.3 & 2.7 \\
\hline Temperature $\left({ }^{\circ} \mathrm{C}\right)$ & 31.0 & 30.0 \\
\hline $\mathrm{pH}$ & 7.4 & 7.5 \\
\hline Conductivity $\left(\mu \mathrm{S} . \mathrm{cm}^{-1}\right)$ & 21.0 & 90.0 \\
\hline Dissolved Oxygen (mg.L $\left.\mathrm{L}^{-1}\right)$ & 8.0 & 7.5 \\
\hline Oxygen saturation $(\%)$ & 110 & 95 \\
\hline Total phosphorus $\left(\mu \mathrm{g} \cdot \mathrm{L}^{-1}\right)$ & 16.87 & 51.87 \\
\hline Total nitrogen mg. $\mathrm{L}^{-1}$ & 1.04 & 0.42 \\
\hline
\end{tabular}



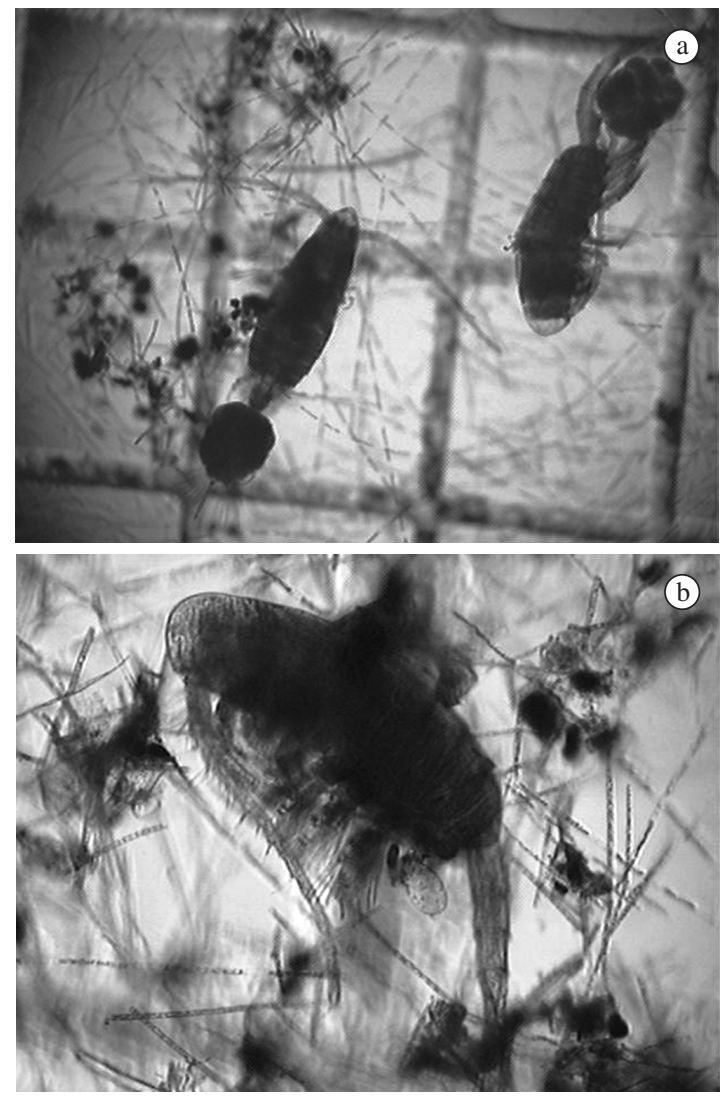

Figure 1. General aspects of; a) female; and b) male.

\section{References}

CIPOLLI, MN. and CARVALHO, MAJ., 1973. Levantamento de Calanoida e Cyclopoida (Copepoda, Crustácea) das águas da região do Guamá, Capim e Tocantins, com nota sobre a fauna acompanhante. Papeis Avulsos Zool., S.Paulo, vol. 27, p. $95-110$.

DAHL, F., 1894. Die Copepodenfauna des unteren Amazonas. Ber. Naturf. Ges. Freiburg. Bd. 8, S. 10-23, 1 Taf.

DUSSART, BH., 1984. Some Crustacean Copepoda from Venezuela. Hydrobiologia, vol. 113, p. 25-67.

MAGALHÃES, A., COSTA, RM., LIANG, TH., PEREIRA, LCC. and RIBEIRO, MJS., 2006. Spatial and temporal

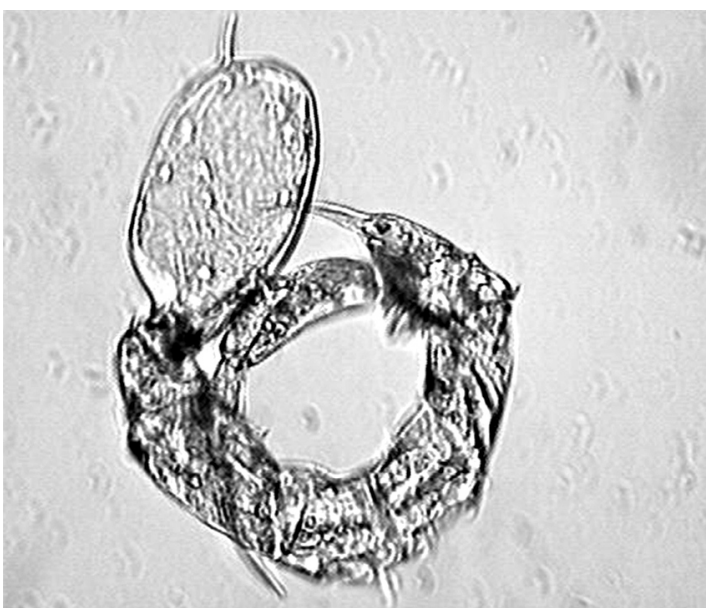

Figure 2. Aspect of fifth leg of male.

distribution in density and biomass of two Pseudodiaptomus species (Copepoda: Calanoida) in the Caeté River estuary (Amazon region - North of Brazil). Braz. J. Biol., vol. 66, no. 2A, p. 421-430.

PRADO-POR, AMS. and LANSAC-TÓHA, FA., 1984. The distribution of brackish water Calanoida ( Copepoda) along the coasts of Brazil. Hydrobiologia, vol. 113, p. 147-150.

STINGELIN, T., 1904. Entomostraken gesammelt von D. Hagmann im Mündungsgebiet des Amazonas. Zool. Jahr. (Syst.) Bd. 20, S. 575-590, 1 Taf.

TUNDISI, JG., 1970. O plâncton estuarino. Contr. Inst. Oceanogr. USP, Série Oceanogr. Biol., vol. 19, p. 1-22.

TUNDISI, J. and MATSUMURA-TUNDISI, T., 1968. Plankton studies in a mangrove environment. V. Salinity tolerances of some planktonic crustaceans. Bolm. Inst. Oceanogr., São Paulo, vol. 17, p. 57-65.

WALTER, TC., 1986. The zoogeography of genus Pseudodiaptomus ( Calanoida: Pseudodiaptomidae). Syllogeus, vol. 58, p. 502-508.

WRIGHT, S., 1928. A contribution to the knowledge of the genus Pseudodiaptomus. Trans. Wisconsin Acad. Sci. Arts and Letters, 2 figs, 1 pl, vol. 23, p. 587-600.

WRIGHT, S., 1936. A revision of the South American species of Pseudodiaptomus. Ann. da Acad. Brasil. Sciencias, Tomo VIII, no. 1. 